\title{
Functions of the Alzheimer's Disease Protease BACE1 at the Synapse in the Central Nervous System
}

\author{
Kathryn M. Munro ${ }^{1}$ Amelia Nash $^{1}$ • Martina Pigoni ${ }^{2,3}$ - Stefan F. Lichtenthaler ${ }^{2,3,4}$. \\ Jenny M. Gunnersen ${ }^{1}$
}

Received: 19 June 2016 / Accepted: 7 July 2016 /Published online: 25 July 2016

(C) The Author(s) 2016. This article is published with open access at Springerlink.com

\begin{abstract}
Inhibition of the protease $\beta$-site amyloid precursor protein-cleaving enzyme 1 (BACE1) is a promising treatment strategy for Alzheimer's disease, and a number of BACE inhibitors are currently progressing through clinical trials. The strategy aims to decrease production of amyloid- $\beta(A \beta)$ peptide from the amyloid precursor protein (APP), thus reducing or preventing $A \beta$ toxicity. Over the last decade, it has become clear that BACE1 proteolytically cleaves a number of substrates in addition to APP. These substrates are not known to be involved in the pathogenesis of Alzheimer's disease but have other roles in the developing and/or mature central nervous system. Consequently, BACE inhibition and knockout in mice results in synaptic and other neuronal dysfunctions and the key substrates responsible for these deficits are still being elucidated. Of the BACE1 substrates that have been validated to date, a number may contribute to the synaptic deficits seen with BACE blockade, including neuregulin 1, close homologue of L1 and seizure-related gene 6. It is important to understand the impact that BACE blockade may have on these
\end{abstract}

Kathryn M. Munro

kathryn.munro@unimelb.edu.au

1 Department of Anatomy and Neuroscience, School of Biomedical Sciences, The University of Melbourne, Parkville, Melbourne, Australia

2 Deutsches Zentrum für Neurodegenerative Erkrankungen (DZNE), Munich, Germany

3 Neuroproteomics, Klinikum rechts der Isar and Institute for Advanced Study, Technische Universität München, 81675 Munich, Germany

4 Munich Cluster for Systems Neurology (SyNergy), Munich, Germany substrates and other proteins detected in substrate screens and, if necessary, develop substrate-selective BACE inhibitors.

Keywords Alzheimer's disease · BACE1 - BACE inhibitors · Synapse $\cdot$ Sez6

\author{
Abbreviations \\ APLP1 Amyloid precursor-like protein 1 \\ APLP2 Amyloid precursor-like protein 2 \\ APP Amyloid precursor protein \\ A $\beta \quad$ Amyloid $\beta$ peptide \\ BACE1 $\beta$-Site amyloid precursor protein-cleaving enzyme 1 \\ CHL1 Close homologue of L1 \\ CSF Cerebrospinal fluid \\ CTF C-terminal fragment \\ CUB Complement subcomponent C1r/C1s, Uegf, Bmp1 \\ EGF Epidermal growth factor \\ KO Knockout \\ LTP Long-term potentiation \\ NRG1 Neuregulin 1 \\ Sez6 Seizure-related gene 6 \\ Sez6L Sez6-like protein \\ Sez6L2 Sez6-like protein 2 \\ SPECS Secretome protein enrichment with click sugars
}

\section{BACE1 Is a Therapeutic Target in Alzheimer's Disease}

Alzheimer's disease is the most common type of dementia and is characterised pathologically by amyloid- $\beta(A \beta)$ plaque deposition and neurofibrillary tangles. Increased levels of $A \beta$ peptide produced by proteolytic cleavage of the amyloid precursor protein (APP) are associated with the formation of 
neurotoxic amyloid aggregates and early synapse loss and neuronal dysfunction (Shankar et al. 2008; Selkoe and Hardy 2016). The $A \beta$ peptide is produced by consecutive cleavage of APP by $\beta$ - and $\gamma$-secretases (Lichtenthaler et al. 2011). Additional APP cleavage products, some of which are neurotoxic, are generated by $\alpha-, \delta$ - and $\eta$-secretases (Lammich et al. 1999; Kuhn et al. 2010; Willem et al. 2015; Zhang et al. 2015). The $\beta$-secretase responsible for the proteolytic processing of APP in the brain is $\beta$-site APP-cleaving enzyme 1 (BACE1) (Vassar et al. 1999). Processing of APP by BACE1 is the rate-limiting step in the production of $A \beta$, and therefore, BACE1 is a major therapeutic target for the treatment of Alzheimer's disease.

BACE1 activity increases in the ageing cortex (Fukumoto et al. 2004), and elevated BACE1 levels can be found in the brains of Alzheimer's disease patients (Fukumoto et al. 2002; Zhao et al. 2007; Hébert et al. 2008). APP mutations in the human population which increase or decrease APP processing by BACE1 can promote or protect against the development of Alzheimer's disease, respectively (Mullan et al. 1992; Jonsson et al. 2012). Knockout of BACE1 prevents $A \beta$ production and improves memory in mouse models of Alzheimer's disease (Cai et al. 2001; Luo et al. 2001; Ohno et al. 2004; Ohno et al. 2006; Ohno et al. 2007). Similarly, the administration of competitive inhibitors of BACE1 improves outcomes in animal models of Alzheimer's disease and provides the rationale for extending this treatment to patients (Vassar et al. 2014). A number of BACE inhibitors are progressing through clinical trials, the most advanced being MK-8931 from Merck which is currently in phase III trials (Evin et al. 2015; Barão et al. 2016; Mullard 2016). Results from these and subsequent clinical trials will demonstrate how safe and effective BACE inhibitors are for the treatment of Alzheimer's disease, and may answer questions regarding the optimal level of BACE inhibition and the utility of this approach for treating patients at different stages of disease (e.g. prodromal vs. asymptomatic patients).

However, over the last decade, it has become clear that BACE1 not only cleaves APP but also has a number of other proteolytic substrates which are not known to be involved in the pathogenesis of Alzheimer's disease but rather have other roles in the central nervous system. Concerns have been raised that mechanism-based side effects of BACE inhibitors may limit their use as therapeutics (Vassar et al. 2014; Evin et al. 2015; Barão et al. 2016). Indeed, recent animal studies have shown that BACE inhibition results in synaptic and cognitive deficits (Filser et al. 2015; Willem et al. 2015) and the production of a newly identified APP peptide, An- $\alpha$, which causes neuronal dysfunction (Willem et al. 2015). Here, we will summarise the synaptic deficits known to result from BACE1 knockout and blockade in mice, and describe key BACE1 substrates that may contribute to this outcome.

\section{Effects of BACE1 Knockout and BACE1 Inhibition on Synaptic and Neuronal Function}

BACE inhibitors are suggested to be most effective when treatment begins very early in the disease pathogenesis (Yan and Vassar 2014), and it is therefore important to know what effect chronic BACE inhibition may have on the brain in the absence of excess levels of $A \beta$ peptide. Constitutive BACE1 knockout (KO) mice provide valuable information about how BACE1 substrates are affected when their proteolytic cleavage is altered. BACE1 KO mice were originally thought to have no significant phenotypes (Luo et al. 2001), but a number of subtle and more severe physiological and behavioural deficits have since been discovered. These include hypomyelination $(\mathrm{Hu}$ et al. 2006; Willem et al. 2006), axon guidance errors in the olfactory bulb (Rajapaksha et al. 2011; Cao et al. 2012) and hippocampus (Hitt et al. 2012), seizures (Kobayashi et al. 2008; Hitt et al. 2010), altered astrogenesis and neurogenesis (Hu et al. 2013), increased likelihood of postnatal death and small size (Dominguez et al. 2005), altered insulin sensitivity (Meakin et al. 2012), decreased anxiety (Laird et al. 2005), schizophrenia endophenotypes (Savonenko et al. 2008) and motor deficits (Kobayashi et al. 2008; Cheret et al. 2013). Notably, BACE1 KO mice also exhibit alterations in synaptic number and function. Reduced spine density, including a decreased proportion of mushroom spines, is seen in CA1 pyramidal neurons of the BACE1 KO hippocampus (Savonenko et al. 2008). BACE1 KO mice display altered synaptic plasticity in CA1 and CA3 regions (Laird et al. 2005; Wang et al. 2008; Wang et al. 2014) which is reflected in deficits in hippocampal-dependent spatial reference and working memory (Laird et al. 2005; Kobayashi et al. 2008).

BACE1 KO mice have a complete loss of BACE1, and while the optimum level of inhibition in patients remains to be determined, complete inhibition of BACE1 proteolytic activity is not the aim. Additionally, BACE1 expression is very high during the first postnatal week in mice (Willem et al. 2006) and some phenotypes of BACE1 KO mice are due to altered processing of substrates during development. Therefore, they may be of limited relevance to BACE1 inhibition in the adult brain, even though some neurodevelopmental processes continue in the adult central nervous system or may be reactivated in the diseased brain. Alternatively, it is possible that the lack of BACE1 during development leads to compensatory changes in constitutive BACE1 KOs, and inhibiting BACE1 in the adult brain may have more pronounced effects on particular substrates than predicted from BACE1 KO mice. Fortunately, serious side effects have not been observed in patients in current clinical trials but mechanism-based side effects could potentially counteract the benefits of BACE inhibition. 
Recent animal studies indicate that BACE blockade in adulthood can have a negative effect on neuronal function. Firstly, BACE inhibition is associated with a reduction in muscle spindles in adult mice (covered in more detail under the section 'Neuregulin 1') (Cheret et al. 2013). Secondly, a study by Willem et al. (2015) demonstrates that BACE inhibitors promote the accumulation of an APP product, A $\eta-\alpha$, which has a detrimental effect on neuronal function. The newly discovered $\eta$-secretase was found to cleave the APP protein; this C-terminal fragment (CTF)- $\eta$ is further processed by BACE1 or $\alpha$-secretase to produce $\mathrm{A} \eta-\alpha$ or A $\eta-\beta$ peptides, respectively. Inhibiting BACE in mice leads to increased levels of the An- $\alpha$ peptide which is detrimental to neuronal function, altering long-term potentiation (LTP) and reducing neuronal activity (Willem et al. 2015). Therefore, BACE inhibition may simultaneously decrease one neurotoxic APP product $(A \beta)$ while increasing another $(A \eta-\alpha)$. Future studies need to clarify whether the increase in $A \eta-\alpha$ seen in mice is also observed in humans. Additionally, it will be essential to understand whether and how An- $\alpha$ contributes to Alzheimer's disease. It is currently unclear how the balance of these two APP peptides will ultimately affect the pathological and cognitive changes in Alzheimer's disease patients. In another recent study, Filser et al. (2015) chronically treated wild-type mice with a BACE inhibitor and identified altered synaptic morphology and function and behavioural deficits. Decreased spine formation on dendrites of cortical pyramidal neurons was observed, which was reversible upon the cessation of treatment. BACE inhibition was shown to decrease neuronal activity and suppress LTP, resulting in memory deficits as assessed by novel object recognition and Y maze spontaneous alternation (Filser et al. 2015). The identification of altered synaptic function and plasticity in the normal adult mouse brain with BACE blockade is significant, as BACE inhibitors may work best if patients are chronically treated from the early stage of the disease. The synaptic and behavioural changes identified by Filser et al. were not attributed to specific BACE1 substrates. There are a number of validated and yet to be validated BACE1 substrates that have known roles in synaptic function and may contribute to the observed results.

Therefore, it is possible that the BACE inhibitors currently being trialled will have some detrimental effects on neuronal function. Inhibition of $\gamma$-secretase was previously a viable therapeutic strategy for Alzheimer's disease, but phase III trials were terminated because of adverse side effects which may have been due to altered processing of the Notch receptor, a $\gamma$-secretase substrate (De Strooper 2014). Like BACE1, $\gamma$-secretase cleaves a number of substrates in addition to APP. While the BACE inhibition strategy is unlikely to have such severe side effects, there are likely to be mechanism-based side effects associated with the use of BACE inhibitors. Important questions remain: what will the short- and long- term consequences of chronic BACE inhibition be in human patients? Would the effects of BACE blockade on synapses still be reversible in humans if treatment were to be continued for an extended period of time? What is the ideal BACE inhibition strategy which decreases $\mathrm{A} \beta$ production while having a minimal impact on other BACE1 substrates? It is important, firstly, to identify the main BACE1 substrates associated with the negative effects on synaptic function and consider whether the BACE inhibitor strategy could be adapted to allow sparing of key substrates, if it should prove necessary.

\section{BACE1 Substrates Associated with Synaptic Function}

Dozens of potential proteolytic substrates of BACE1 have been identified over the last decade, many of which have been identified through proteomic studies (Hemming et al. 2009; Kuhn et al. 2012; Zhou et al. 2012; Hogl et al. 2013; Dislich et al. 2015), and some substrates have been validated in vitro or in vivo by analysing cleaved substrate products in the vertebrate brain or cerebrospinal fluid (CSF). Of these validated substrates, several have known roles in synaptic function and these substrates are discussed below.

\section{Neuregulin 1}

Neuregulin 1 (NRG1) is a member of the neuregulin family of epidermal growth factor (EGF)-like proteins which are ligands for ErbB tyrosine kinase receptors. NRG1 has multiple isoforms that arise from alternative splicing, and these are categorised into six types based on structure (NRG1 types I-VI). All of these isoforms contain an extracellular EGF-like domain; proteolytic cleavage of transmembrane NRG1 is required for the release of the portion of the protein containing this domain, and this soluble form can then bind and activate ErbB receptors (Mei and Nave 2014). NRG1 has a range of biological functions in the central and peripheral nervous systems including the regulation of myelination, radial and tangential neuronal migration (of glutamatergic and GABAergic neurons, respectively) and synaptic plasticity (Mei and Nave 2014). Thus, inhibition or loss of BACE1 activity is predicted to alter NRG1-ErbB signalling and, in fact, a number of the phenotypes seen in BACE1 KO mice are attributed to the lack of BACE1 cleavage of NRG1. For example, BACE1 cleavage of neuronally expressed NRG1 type III is required for normal myelination. BACE1 KO mice, as well as zebrafish lacking BACE1, have peripheral hypomyelination (Hu et al. 2006; Willem et al. 2006; Hu et al. 2008; van Bebber et al. 2013), and central hypomyelination has also been reported (Hu et al. 2006). The proteolytic processing of NRG1 type III and the consequences for myelination have been recently reviewed (Fleck et al. 2012; Hu et al. 2016) and will not be described in detail here. 
NRG1-ErbB4 signalling has been intensively studied since the respective genes encoding these proteins were identified as schizophrenia susceptibility genes (Stefansson et al. 2002; Corvin et al. 2004; Mei and Nave 2014; Mostaid et al. 2016). NRG1 heterozygous mice display schizophrenia-like endophenotypes and impaired hippocampal plasticity (Stefansson et al. 2002; O'Tuathaigh et al. 2010), and similar schizophrenia-related endophenotypes are seen in BACE1 $\mathrm{KO}$ mice (including impaired pre-pulse inhibition, a greater level of hyperactivity induced by a glutamatergic psychostimulant, cognitive impairments and social recognition deficits; Savonenko et al. 2008). A reduction in PSD95-associated ErbB4 was also observed in these BACE1 KO mice, supporting the idea that the lack of BACE1 processing of NRG1 and subsequent impairment of NRG1-ErbB4 signalling contributed to the phenotypes observed (Savonenko et al. 2008). Taken together, there is strong evidence from NRG1 overexpression and knockout studies in mice (Mostaid et al. 2016) for the association of altered developmental NRG1ErbB4 signalling with schizophrenia; however, relatively few studies have addressed the role of BACE1-cleaved NRG1 in the mature brain.

The persistence of NRG1 and ErbB4 expression in the adult central nervous system, including in neurons of the cortex and hippocampus, indicates ongoing roles for NRG1 signalling in maturity (Mei and Xiong 2008). NRG1-ErbB4 signalling is important in regulating synaptic function at both excitatory and inhibitory synapses. For example, ErbB4 is recruited in an activity-dependent manner to the postsynaptic compartment of hippocampal CA1 excitatory synapses where it is activated by soluble NRG1. Binding of NRG1 enhances ErbB4 association with PSD-95 in the postsynaptic scaffold, strengthening glutamatergic synapses through stabilising synaptic AMPA receptors and maintaining dendritic spine synapses ( $\mathrm{Li}$ et al. 2007). While loss of NRG1-ErbB4 signalling is detrimental (Li et al. 2007; Agarwal et al. 2014), excessive NRG1-ErbB4 activity (as seen in schizophrenia) is also associated with synaptic dysfunction resulting from suppression of LTP-induced NMDA receptor function (Pitcher et al. 2011; Agarwal et al. 2014; Luo et al. 2014).

ErbB4 is also expressed in interneurons in the postnatal and adult brains and is required presynaptically in cortical GABAergic axon terminals for the formation of inhibitory synapses onto pyramidal neurons (Mei and Nave 2014). In dendrites of interneurons, ErbB4 acts postsynaptically at excitatory synapses (Fazzari et al. 2010). Interestingly, deletion of ErbB4 only in fast-spiking interneurons produced neurophysiological and behavioural deficits consistent with schizophrenia endophenotypes (Del Pino et al. 2013). Thus, NRG1 function must be precisely regulated to maintain normal glutamatergic receptor functions at synapses and balanced excitatory-inhibitory neurotransmission in the cortex.
Another important ongoing role of BACE1-processed NRG1 and NRG1-ErbB signalling is the maintenance of muscle spindles, sensory receptors that detect changes in muscle length (Cheret et al. 2013). Chronic treatment of adult wild-type mice with a BACE inhibitor led to a substantial loss of spindles and consequent impairment in motor co-ordination (Cheret et al. 2013). Careful assessment of motor function in patients during chronic BACE inhibitor treatment will be necessary to monitor this potential side effect.

\section{Sez6 Family}

The seizure-related gene 6 (Sez6; also referred to as Seizure 6, Seizure protein 6 and BSRP) family of proteins includes Sez6, Sez6-like (Sez6L) and Sez6-like 2 (Sez6L2). All three family members were identified as BACE1 substrates from a screen that identified proteins shed from cultured neurons using the secretome protein enrichment with click sugars (SPECS) method (Kuhn et al. 2012). Sez6 was validated as a BACE1 substrate, and Sez6 and Sez6L were found to be cleaved predominantly or exclusively by BACE1 (Kuhn et al. 2012). Sez6 is a prime candidate for involvement in the synaptic dysfunction seen with BACE inhibition (Filser et al. 2015) as it is expressed in the adult brain and has known roles in dendrite and spine development (Gunnersen et al. 2007). Given the growing interest in Sez6 family proteins as BACE1 substrates, we have provided a comprehensive coverage of the literature below.

Sez6 messenger RNA (mRNA) is upregulated by neuronal activity (Shimizu-Nishikawa et al. 1995b) and predominantly localised to the central nervous system (Shimizu-Nishikawa et al. 1995b; Herbst and Nicklin 1997). High levels of Sez6 protein are found in the developing and postnatal forebrain (Kim et al. 2002; Gunnersen et al. 2007; Osaki et al. 2011), with Sez6 being detected in the somatodendritic compartment of neurons (Miyazaki et al. 2006; Gunnersen et al. 2007). Sez6 mRNA and protein expression remains relatively high in regions of the adult mouse central nervous system including the cortex, hippocampus, striatum, olfactory tubercule (Herbst and Nicklin 1997; Miyazaki et al. 2006; Gunnersen et al. 2007; Osaki et al. 2011), retina (Gunnersen et al. 2009) and spinal cord (B Graham and J Gunnersen, unpublished data). In constitutive Sez6 KO mice, neurons exhibit morphological alterations including an increased number of dendrites and fewer spines (Gunnersen et al. 2007). Both BACE1 KO and Sez6 KO mice have reduced dendritic spine densities (Savonenko et al. 2008; Gunnersen et al. 2007), deficits in hippocampal-dependent learning (Laird et al. 2005; Gunnersen et al. 2007) and motor deficits (Kobayashi et al. 2008; Gunnersen et al. 2007). The Sez6 gene is highly conserved between mice and humans, and sez 6 mutations and/or altered expression has been associated with febrile seizures (Yu et al. 2007; Mulley et al. 2011), autism spectrum disorder (Cukier et al. 2014; Mariani et al. 2015), intellectual disability 
(Gilissen et al. 2014) and childhood-onset schizophrenia (Ambalavanan et al. 2016). Elevated, or decreased, levels of Sez6 in the CSF are observed in adult patients with psychiatric disorders (Maccarrone et al. 2013) and Alzheimer's disease (Khoonsari et al. 2016), respectively.

Sez6 family proteins are each represented by multiple isoforms. Full-length type I transmembrane protein isoforms consist of a signal sequence, a large extracellular or luminal region containing complement subcomponent C1r/C1s, Uegf, Bmp1 (CUB) domains and sushi (also known as short consensus repeat [SCR] or complement control protein $[\mathrm{CCP}]$ ) domains, a transmembrane region and a short intracellular region containing an NPxY motif, potential phosphorylation sites (Shimizu-Nishikawa et al. 1995b; Miyazaki et al. 2006) and a potential PDZ protein binding domain at the C-terminus ( $\mathrm{J}$ Gunnersen, unpublished). The presence of CUB and sushi domains suggests that Sez6 family proteins interact with other central nervous system proteins, and an interaction between Sez6 and the protease neurotrypsin (also known as motopsin) has been reported (Mitsui et al. 2013). From the single sez6 gene, two different transmembrane protein isoforms and a truncated isoform lacking the transmembrane region (secreted) are generated via alternative splicing of the sez6 mRNA (Shimizu-Nishikawa et al. 1995a; Miyazaki et al. 2006). Sez6 transmembrane and secreted isoforms have opposing actions on dendritic outgrowth in vitro (Gunnersen et al. 2007). Overexpression of the fulllength transmembrane Sez6 in neurons lacking endogenous Sez6 inhibits neurite outgrowth while secreted Sez6 promotes it. BACE1 cleaves the transmembrane form of Sez6 to produce a shed ectodomain that is similar to (although larger than) the secreted Sez6 isoform (Kuhn et al. 2012). It will be important to determine whether the BACE1-shed Sez6 ectodomain performs a similar functional role to the secreted isoform, as effective BACE inhibition would be expected to block ectodomain shedding while enhancing the levels of the intact transmembrane form, as shown in mice (Kuhn et al. 2012).

Like Sez6, Sez6L and Sez6L2 are localised to the somatodendritic compartment of neurons (Miyazaki et al. 2006). Sez6L and Sez6L2 mRNA is found throughout the adult mouse brain in regions including the cortex, hippocampus and olfactory bulb (Miyazaki et al. 2006). Mice lacking all Sez6 family members (triple KO mice) have significant motor co-ordination deficits attributed to abnormal climbing fibre innervation in the cerebellum; loss of Sez6L appears to be mostly responsible for this phenotype. The lack of reported phenotypes in the single $\mathrm{KO}$ mouse lines in this study indicates a level of functional redundancy between Sez6 family members (Miyazaki et al. 2006). Nevertheless, knockdown of individual Sez6 family members results in decreased calcium spiking frequency and amplitude in cultured neurons (Anderson et al. 2012).

Sez6L was also identified by Kuhn et al. (2012) as a BACE substrate using SPECS. Although not yet validated by other means, further investigation is warranted as, like Sez6, it is predominantly cleaved by BACE1 rather than other proteases (Kuhn et al. 2012). Little is known about its neuronal function although Sez6L mRNA is widely expressed in the adult brain in regions including the cortex and hippocampus (Miyazaki et al. 2006). Sez6L is linked to bipolar disorder ( $\mathrm{Xu}$ et al. 2013). Outside the central nervous system, sez6L genetic variants are associated with multiple cancer types, inflammation and cardiovascular disease. Sez6L2 has been linked to autism (Kumar et al. 2009; Konyukh et al. 2011; Chapman et al. 2015) and is likely to play an important role in central nervous system development. Levels of the shed Sez6L2 ectodomain are decreased in the CSF of BACE1 KO mice (Dislich et al. 2015), although Sez6L2 is likely to be cleaved by other proteases in addition to BACE1 (Kuhn et al. 2012) and cathepsin $\mathrm{D}$ is one such protease (Boonen et al. 2016). In this report, Sez6L2 was identified as a transport receptor for cathepsin D, an aspartyl protease found in lysosomes, and was localised to endosomes, the trans-Golgi network and the plasma membrane. Similarly to Sez6, full-length and proteolytically cleaved Sez6L2 exhibited opposing effects on neuronal differentiation and neurite outgrowth in neuroblastoma cells (Boonen et al. 2016). Sez6L and Sez6L2 are expressed in the pancreas where they are BACE2 but not BACE1 substrates, demonstrating the tissue-specific cleavage of these proteins. The CTFs of BACE2-cleaved Sez6L and Sez6L2 are subsequently cleaved by $\gamma$-secretase (Stützer et al. 2013), raising the possibility that Sez6 family proteins may undergo this secondary cleavage in the central nervous system.

To understand how Sez6 family proteins contribute to the synaptic deficits seen with BACE inhibition, we need to investigate more fully the functions of uncleaved Sez6 and the BACE1-cleaved Sez6 ectodomain, and learn more about the roles of Sez6L and Sez6L2 in the adult central nervous system.

\section{CHL1 and L1}

L1 (also called L1 cell adhesion molecule) and close homologue of L1 (CHL1) are members of the L1 family of cell adhesion molecules and part of the immunoglobulin superfamily. CHL1 and L1 are type I transmembrane proteins which are widely expressed in neurons, particularly in the developing central nervous system where they facilitate neurite outgrowth, axonal targeting and cell migration (Hillenbrand et al. 1999; Maness and Schachner 2007). CHL1 and L1 cleavage by ADAM proteases alters their 
function, likely through the release of extracellular fragments or reduction of cell adhesion (Maness and Schachner 2007). CHL1 and L1 were identified as neuronal BACE1 substrates through proteomic screening (Kuhn et al. 2012; Zhou et al. 2012), and they have been validated as physiological BACE1 substrates in vivo (Hitt et al. 2012; Kuhn et al. 2012; Zhou et al. 2012; Dislich et al. 2015).

Neuronal CHL1 is enriched in the axonal membrane (Leshchyns'ka et al. 2006), and co-localisation with BACE1 is observed in growth cones in vitro and pre-synaptic terminals in the postnatal mouse brain (Hitt et al. 2012). Similar hippocampal mossy fibre and olfactory sensory neuron axon guidance defects are observed in constitutive CHL1 KO (Montag-Sallaz et al. 2002) and BACE1 KO mice (Rajapaksha et al. 2011; Cao et al. 2012; Hitt et al. 2012), suggesting that BACE1 processing of CHL1 is required for normal axon targeting. BACE1 cleavage of CHL1 has been shown to contribute to growth cone collapse through interactions of the CHL1-CTF with the axonal guidance molecule semaphorin 3A (Barão et al. 2015).

CHL1 expression decreases following development but persists in the mature central nervous system (Hillenbrand et al. 1999), indicating an ongoing function of CHL1 in the adult brain. CHL1 has a demonstrated role in synaptic transmission: CHL1 accumulates in the pre-synaptic membrane and, through an association of the CHL1 intracellular domain with the chaperone Hsc70, regulates the uncoating of clathrincoated synaptic vesicles (Leshchyns'ka et al. 2006). Conditional KO mice, in which CHL1 was ablated in excitatory forebrain neurons following postnatal development, exhibited an impaired working memory duration (Kolata et al. 2008) indicating a role for CHL1 in this process in the mature brain. Similarly, L1 is expressed in neurons of the adult brain including the cerebral cortex and hippocampus (Hillenbrand et al. 1999; Horinouchi et al. 2005). Conditional KO mice in which L1 is deleted in mature excitatory forebrain neurons do not display the severe developmental abnormalities seen in constitutive L1 KO mice (Maness and Schachner 2007). However, conditional L1 KO mice display increased basal excitatory activity in hippocampal CA1 and use different search strategies in the Morris water maze, indicating an alteration in place learning (Law et al. 2003).

\section{APP Family}

The APP peptide A $\eta-\alpha$, while not a BACE1 product, is detrimental to neuronal function and is increased in the presence of BACE inhibitors as discussed previously (Willem et al. 2015). Full-length APP and its peptide products also have non-toxic physiological roles related to cell adhesion, intracellular signalling, synaptic function and more, reviewed in detail elsewhere (Müller and Zheng 2012; Nhan et al. 2015). Cleavage of APP by $\alpha$-secretase or BACE1 leads to the release of soluble ectodomains APPs $\alpha$ and APPs $\beta$, respectively. APPs $\alpha$ has synaptotropic and neuroprotective properties; however, APPs $\beta$ has not been shown to have the same potent effect on synapses (Hick et al. 2015; Nhan et al. 2015). The cytoplasmic domain of APP also has a demonstrated role in normal synaptic function (Klevanski et al. 2015). Within the same gene family are amyloid precursor-like protein 1 (APLP1) and amyloid precursor-like protein 2 (APLP2), expressed in the adult brain (Lorent et al. 1995). APLP1 and APLP2 are also type I transmembrane proteins that undergo cleavage by secretases, including BACE1 (Eggert et al. 2004; Li and Südhof 2004; Hogl et al. 2011), to produce a soluble ectodomain, intracellular domain and other (non-A $\beta$ ) peptide fragments. Neuronal APLP1 is almost exclusively cleaved by BACE1 (Kuhn et al. 2012); however, relatively little is known about its function. Constitutive APLP1 KO mice display altered synaptic transmission in the dentate gyrus, but to date, there is no clear role for APLP1 in synaptic plasticity (Vnencak et al. 2015). Further study is needed to determine how BACE processing affects APLP1 function.

\section{Additional BACE1 Substrates}

Other potential BACE1 substrates with known roles in synaptic function have been identified in proteolytic screens but await validation in vitro or in vivo. For example, neuroligin $1 \alpha$, neuroligin 2 , neuroligin 4 and neurexin $1 \alpha$, well-known synaptic cell adhesion molecules, have been identified as likely neuronal BACE1 substrates (Kuhn et al. 2012; Bemben et al. 2015). BACE1 substrates also include proteins that influence the excitability of neurons, including the $\beta$ subunits of voltage-gated sodium channels (Wong et al. 2005; Kim et al. 2007; Gersbacher et al. 2010) and subunits of voltage-gated potassium channel proteins, KCNE1 and KCNE2 (Sachse et al. 2013). The BACE1 substrate contactin-2 (Kuhn et al. 2012; Zhou et al. 2012) is a cell adhesion molecule that, together with CASPR2, maintains voltage-gated potassium channels at juxtaparanodal regions of myelinated axons (Poliak et al. 2003). Additionally, while BACE1 primarily acts as a protease, BACE1 can interact nonproteolytically with voltage-dependent sodium channels (Huth et al. 2009) and KCNQ potassium channels (Hessler et al. 2015). Therefore, BACE blockade may alter neuronal excitability through multiple mechanisms.

\section{Neuronal Localisation of BACE1}

Identifying the subcellular compartments in which BACE1 interacts with APP and its additional substrates may promote the development of BACE inhibitors that are 'substrate 
sparing', if adverse mechanism-based side effects of this treatment are found.

BACE1 is expressed in neurons in multiple areas of the healthy and diseased adult brain, including the cortex and hippocampus (Vassar et al. 1999; Fukumoto et al. 2002). In human and mouse neurons, BACE1 is detected in the axonal and somatodendritic compartments; in mouse neurons, BACE1 is transported to, and enriched in, axons (BuggiaPrévot et al. 2013; Buggia-Prévot et al. 2014). BACE1 is prominent in pre-synaptic terminals, and levels are high in the terminals of dystrophic neurites surrounding $A \beta$ plaques (Laird et al. 2005; Zhao et al. 2007; Kandalepas et al. 2013; Sadleir et al. 2016).

BACE1 activity is greatest at acidic $\mathrm{pH}$ and can be indirectly inhibited with drugs, such as bepridil, which alkalize the membrane-proximal areas of acidic organelles (Mitterreiter et al. 2010). A recent study by Das et al. (2016) determined that the main subcellular interaction sites of BACE1 and APP in cultured hippocampal neurons depend on the neuronal compartment. In dendrites, including dendritic spines, interaction is most frequent in recycling endosomes with fewer interactions occurring in early endosomal, lysosomal and Golgi vesicles. In axons, the majority of BACE1APP interactions occur in Golgi-derived vesicles (Das et al. 2016). Validated BACE1 substrates have varied subcellular locations. For example CHL1, L1 and contactin-2 are enriched in axons while Sez6 is localised to the somatodendritic compartment (Gunnersen et al. 2007). Sez6 has been shown to be internalised from the surface of cultured neurons and to be present in transferrin receptor (TfR)-positive early/recycling endosomes (Carrodus et al. 2014); however, further experiments are required to determine whether this compartment is the site of the BACE1-Sez6 interaction.

Identification of the BACE1 substrates that are required for normal synaptic function in the mature brain and elucidation of their subcellular locations will help determine strategies to modify the BACE inhibition approach, if required. For example, experimental approaches to decrease $\mathrm{A} \beta$ production while minimising the blockade of key BACE1 substrates include altering the trafficking of BACE1 (Kizuka et al. 2015) and using an endosomally targeted BACE inhibitor (Ben Halima et al. 2016). However, it is possible that the latter strategy will not spare all substrates, as Sez6 family proteins are also abundant in endosomes (Miyazaki et al. 2006; Carrodus et al. 2014).

\section{Summary}

BACE inhibitors for the treatment of Alzheimer's disease are progressing through clinical trials. If this strategy is found to be effective in preventing or reducing cognitive decline in Alzheimer's disease patients, considerations for the use of
BACE inhibitors include identifying the stage at which the treatment should begin, determining the ideal levels of BACE inhibition at different disease stages and investigating the benefit of combining BACE inhibitors with additional therapeutic strategies. Furthermore, a level of caution surrounds the BACE inhibitor strategy as BACE1 has a number of other substrates in addition to APP. It is imperative that we understand the effects of altered BACE1 cleavage of key substrates and, if warranted, aim to adapt the BACE inhibitor strategy to minimise mechanism-based side effects. Therefore, gaining a better understanding of the fundamental roles of BACE1 substrates in the adult brain and how (and in which subcellular compartments) BACE1 cleavage modulates these functions is of the utmost importance.

Acknowledgments K. M. Munro is supported by National Health and Medical Research (NHMRC)—Australian Research Council (ARC) Dementia Research Development Fellowship 1100324. Work in the Gunnersen lab is supported by NHMRC Project Grant 1058672. Work in the Lichtenthaler lab is supported by the Deutsche Forschungsgemeinschaft (FOR 2290), the Center for Excellence in Neurodegeneration (CoEN), the Breuer Foundation research award and the Agency for Innovation by Science and Technology (IWT).

Open Access This article is distributed under the terms of the Creative Commons Attribution 4.0 International License (http:// creativecommons.org/licenses/by/4.0/), which permits unrestricted use, distribution, and reproduction in any medium, provided you give appropriate credit to the original author(s) and the source, provide a link to the Creative Commons license, and indicate if changes were made.

\section{References}

Agarwal A, Zhang M, Trembak-Duff I, Unterbarnscheidt T, Radyushkin K, Dibaj P, Martins de Souza D, Boretius S, Brzózka MM, Steffens H, Berning S, Teng Z, Gummert MN, Tantra M, Guest PC, Willig KI, Frahm J, Hell SW, Bahn S, Rossner MJ, Nave KA, Ehrenreich H, Zhang W, Schwab MH (2014) Dysregulated expression of neuregulin-1 by cortical pyramidal neurons disrupts synaptic plasticity. Cell Rep 8:1130-1145

Ambalavanan A, Girard SL, Ahn K, Zhou S, Dionne-Laporte A, Spiegelman D, Bourassa CV, Gauthier J, Hamdan FF, Xiong L, Dion PA, Joober R, Rapoport J, Rouleau GA (2016) De novo variants in sporadic cases of childhood onset schizophrenia. Eur J Hum Genet 24:944-948

Anderson GR, Galfin T, Xu W, Aoto J, Malenka RC, Südhof TC (2012) Candidate autism gene screen identifies critical role for celladhesion molecule CASPR2 in dendritic arborization and spine development. Proc Natl Acad Sci U S A 109:18120-18125

Barão S, Moechars D, Lichtenthaler SF, De Strooper B (2016) BACE1 physiological functions may limit its use as therapeutic target for Alzheimer's disease. Trends Neurosci 39:158-169

Barão S, Gärtner A, Leyva-Díaz E, Demyanenko G, Munck S, Vanhoutvin T, Zhou L, Schachner M, López-Bendito G, Maness PF, De Strooper B (2015) Antagonistic effects of BACE1 and APH1B- $\gamma$-secretase control axonal guidance by regulating growth cone collapse. Cell Rep 12:1367-1376

Bemben MA, Shipman SL, Nicoll RA, Roche KW (2015) The cellular and molecular landscape of neuroligins. Trends Neurosci 38:496-505 
Ben Halima S, Mishra S, Raja KM, Willem M, Baici A, Simons K, Brüstle O, Koch P, Haass C, Caflisch A, Rajendran L (2016) Specific inhibition of $\beta$-secretase processing of the Alzheimer disease amyloid precursor protein. Cell Rep 14:2127-2141

Boonen M, Staudt C, Gilis F, Oorschot V, Klumperman J, Jadot M (2016) Cathepsin D and its newly identified transport receptor SEZ6L2 can modulate neurite outgrowth. J Cell Sci 129:557-568

Buggia-Prévot V, Fernandez CG, Riordan S, Vetrivel KS, Roseman J, Waters J, Bindokas VP, Vassar R, Thinakaran G (2014) Axonal BACE1 dynamics and targeting in hippocampal neurons: a role for Rab11 GTPase. Mol Neurodegener 9:1

Buggia-Prévot V, Fernandez CG, Udayar V, Vetrivel KS, Elie A, Roseman J, Sasse VA, Lefkow M, Meckler X, Bhattacharyya S, George M, Kar S, Bindokas VP, Parent AT, Rajendran L, Band H, Vassar R, Thinakaran G (2013) A function for EHD family proteins in unidirectional retrograde dendritic transport of BACE1 and Alzheimer's disease A $\beta$ production. Cell Rep 5:1552-1563

Cai H, Wang Y, McCarthy D, Wen H, Borchelt DR, Price DL, Wong PC (2001) BACE1 is the major beta-secretase for generation of Abeta peptides by neurons. Nat Neurosci 4:233-234

Cao L, Rickenbacher GT, Rodriguez S, Moulia TW, Albers MW (2012) The precision of axon targeting of mouse olfactory sensory neurons requires the BACE1 protease. Sci Rep 2:231

Carrodus NL, Teng KS, Munro KM, Kennedy MJ, Gunnersen JM (2014) Differential labeling of cell-surface and internalized proteins after antibody feeding of live cultured neurons. J Vis Exp (84):e51139. doi:10.3791/51139

Chapman NH, Nato AQ, Bernier R, Ankenman K, Sohi H, Munson J, Patowary A, Archer M, Blue EM, Webb SJ, Coon H, Raskind WH, Brkanac Z, Wijsman EM (2015) Whole exome sequencing in extended families with autism spectrum disorder implicates four candidate genes. Hum Genet 134:1055-1068

Cheret C, Willem M, Fricker FR, Wende H, Wulf-Goldenberg A, Tahirovic S, Nave KA, Saftig P, Haass C, Garratt AN, Bennett DL, Birchmeier C (2013) Bace1 and neuregulin-1 cooperate to control formation and maintenance of muscle spindles. EMBO J 32: 2015-2028

Corvin AP, Morris DW, McGhee K, Schwaiger S, Scully P, Quinn J, Meagher D, Clair DS, Waddington JL, Gill M (2004) Confirmation and refinement of an 'at-risk' haplotype for schizophrenia suggests the EST cluster, Hs.97362, as a potential susceptibility gene at the neuregulin-1 locus. Mol Psychiatry 9:208-213

Cukier HN, Dueker ND, Slifer SH, Lee JM, Whitehead PL, Lalanne E, Leyva N, Konidari I, Gentry RC, Hulme WF, Booven DV, Mayo V, Hofmann NK, Schmidt MA, Martin ER, Haines JL, Cuccaro ML, Gilbert JR, Pericak-Vance MA (2014) Exome sequencing of extended families with autism reveals genes shared across neurodevelopmental and neuropsychiatric disorders. Mol Autism 5:1

Das U, Wang L, Ganguly A, Saikia JM, Wagner SL, Koo EH, Roy S (2016) Visualizing APP and BACE-1 approximation in neurons yields insight into the amyloidogenic pathway. Nat Neurosci 19:55-64

De Strooper B (2014) Lessons from a failed $\gamma$-secretase Alzheimer trial. Cell 159:721-726

Del Pino I, García-Frigola C, Dehorter N, Brotons-Mas JR, AlvarezSalvado E, Martínez de Lagrán M, Ciceri G, Gabaldón MV, Moratal D, Dierssen M, Canals S, Marín O, Rico B (2013) Erbb4 deletion from fast-spiking interneurons causes schizophrenia-like phenotypes. Neuron 79:1152-1168

Dislich B, Wohlrab F, Bachhuber T, Müller SA, Kuhn PH, Hogl S, Meyer-Luehmann M, Lichtenthaler SF (2015) Label-free quantitative proteomics of mouse cerebrospinal fluid detects $\beta$-site APP cleaving enzyme (BACE1) protease substrates in vivo. Mol Cell Proteomics 14:2550-2563

Dominguez D, Tournoy J, Hartmann D, Huth T, Cryns K, Deforce S, Serneels L, Camacho IE, Marjaux E, Craessaerts K, Roebroek AJ,
Schwake M, D'Hooge R, Bach P, Kalinke U, Moechars D, Alzheimer C, Reiss K, Saftig P, De Strooper B (2005) Phenotypic and biochemical analyses of BACE1- and BACE2-deficient mice. J Biol Chem 280:30797-30806

Eggert S, Paliga K, Soba P, Evin G, Masters CL, Weidemann A, Beyreuther K (2004) The proteolytic processing of the amyloid precursor protein gene family members APLP-1 and APLP-2 involves alpha-, beta-, gamma-, and epsilon-like cleavages: modulation of APLP-1 processing by n-glycosylation. J Biol Chem 279:18146-18156

Evin G, Fuller SJ, Gunnersen JM (2015) BACE inhibition as a therapeutic strategy for Alzheimer's disease. Frontiers in Clinical Drug Research - Alzheimer Disorders, 2015 3:135-230

Fazzari P, Paternain AV, Valiente M, Pla R, Luján R, Lloyd K, Lerma J, Marín O, Rico B (2010) Control of cortical GABA circuitry development by Nrg1 and ErbB4 signalling. Nature 464:1376-1380

Filser S, Ovsepian SV, Masana M, Blazquez-Llorca L, Brandt Elvang A, Volbracht C, Müller MB, Jung CK, Herms J (2015) Pharmacological inhibition of BACE1 impairs synaptic plasticity and cognitive functions. Biol Psychiatry 77:729-739

Fleck D, Garratt AN, Haass C, Willem M (2012) BACE1 dependent neuregulin processing: review. Curr Alzheimer Res 9:178-183

Fukumoto H, Cheung BS, Hyman BT, Irizarry MC (2002) Beta-secretase protein and activity are increased in the neocortex in Alzheimer disease. Arch Neurol 59:1381-1389

Fukumoto H, Rosene DL, Moss MB, Raju S, Hyman BT, Irizarry MC (2004) Beta-secretase activity increases with aging in human, monkey, and mouse brain. Am J Pathol 164:719-725

Gersbacher MT, Kim DY, Bhattacharyya R, Kovacs DM (2010) Identification of BACE1 cleavage sites in human voltage-gated sodium channel beta 2 subunit. Mol Neurodegener 5:61

Gilissen C, Hehir-Kwa JY, Thung DT, van de Vorst M, van Bon BW, Willemsen MH, Kwint M, Janssen IM, Hoischen A, Schenck A, Leach R, Klein R, Tearle R, Bo T, Pfundt R, Yntema HG, de Vries BB, Kleefstra T, Brunner HG, Vissers LE, Veltman JA (2014) Genome sequencing identifies major causes of severe intellectual disability. Nature 511:344-347

Gunnersen JM, Kuek A, Phipps JA, Hammond VE, Puthussery T, Fletcher EL, Tan SS (2009) Seizure-related gene 6 (Sez-6) in amacrine cells of the rodent retina and the consequence of gene deletion. PLoS One 4:e6546

Gunnersen JM, Kim MH, Fuller SJ, De Silva M, Britto JM, Hammond VE, Davies PJ, Petrou S, Faber ES, Sah P, Tan SS (2007) Sez-6 proteins affect dendritic arborization patterns and excitability of cortical pyramidal neurons. Neuron 56:621-639

Hemming ML, Elias JE, Gygi SP, Selkoe DJ (2009) Identification of betasecretase (BACE1) substrates using quantitative proteomics. PLoS One 4:e8477

Herbst R, Nicklin MJ (1997) SEZ-6: promoter selectivity, genomic structure and localized expression in the brain. Brain Res Mol Brain Res 44:309-322

Hessler S, Zheng F, Hartmann S, Rittger A, Lehnert S, Völkel M, Nissen M, Edelmann E, Saftig P, Schwake M, Huth T, Alzheimer C (2015) $\beta$-Secretase BACE1 regulates hippocampal and reconstituted $\mathrm{M}$ currents in a $\beta$-subunit-like fashion. J Neurosci 35:3298-3311

Hick M, Herrmann U, Weyer SW, Mallm JP, Tschäpe JA, Borgers M, Mercken M, Roth FC, Draguhn A, Slomianka L, Wolfer DP, Korte M, Müller UC (2015) Acute function of secreted amyloid precursor protein fragment APPs $\alpha$ in synaptic plasticity. Acta Neuropathol 129:21-37

Hillenbrand R, Molthagen M, Montag D, Schachner M (1999) The close homologue of the neural adhesion molecule L1 (CHL1): patterns of expression and promotion of neurite outgrowth by heterophilic interactions. Eur J Neurosci 11:813-826

Hitt B, Riordan SM, Kukreja L, Eimer WA, Rajapaksha TW, Vassar R (2012) $\beta$-Site amyloid precursor protein (APP)-cleaving enzyme 1 
(BACE1)-deficient mice exhibit a close homolog of L1 (CHL1) loss-of-function phenotype involving axon guidance defects. J Biol Chem 287:38408-38425

Hitt BD, Jaramillo TC, Chetkovich DM, Vassar R (2010) BACE1-/- mice exhibit seizure activity that does not correlate with sodium channel level or axonal localization. Mol Neurodegener 5:31

Hogl S, Kuhn PH, Colombo A, Lichtenthaler SF (2011) Determination of the proteolytic cleavage sites of the amyloid precursor-like protein 2 by the proteases ADAM10, BACE1 and $\gamma$-secretase. PLoS One 6:e21337

Hogl S, van Bebber F, Dislich B, Kuhn PH, Haass C, Schmid B, Lichtenthaler SF (2013) Label-free quantitative analysis of the membrane proteome of BACE1 protease knock-out zebrafish brains. Proteomics 13:1519-1527

Horinouchi K, Nakamura Y, Yamanaka H, Watabe T, Shiosaka S (2005) Distribution of L1cam mRNA in the adult mouse brain: in situ hybridization and Northern blot analyses. J Comp Neurol 482:386-404

Hu X, Fan Q, Hou H, Yan R (2016) Neurological dysfunctions associated with altered BACE1-dependent neuregulin-1 signaling. J Neurochem 136:234-249

Hu X, He W, Luo X, Tsubota KE, Yan R (2013) BACE1 regulates hippocampal astrogenesis via the Jagged1-Notch pathway. Cell Rep 4:40-49

Hu X, Hicks CW, He W, Wong P, Macklin WB, Trapp BD, Yan R (2006) BACE1 modulates myelination in the central and peripheral nervous system. Nat Neurosci 9:1520-1525

Hu X, He W, Diaconu C, Tang X, Kidd GJ, Macklin WB, Trapp BD, Yan R (2008) Genetic deletion of BACE1 in mice affects remyelination of sciatic nerves. FASEB J 22:2970-2980

Huth T, Schmidt-Neuenfeldt K, Rittger A, Saftig P, Reiss K, Alzheimer C (2009) Non-proteolytic effect of beta-site APP-cleaving enzyme 1 (BACE1) on sodium channel function. Neurobiol Dis 33:282-289

Hébert SS, Horré K, Nicolaï L, Papadopoulou AS, Mandemakers W, Silahtaroglu AN, Kauppinen S, Delacourte A, De Strooper B (2008) Loss of microRNA cluster miR-29a/b-1 in sporadic Alzheimer's disease correlates with increased BACE1/betasecretase expression. Proc Natl Acad Sci U S A 105:6415-6420

Jonsson T, Atwal JK, Steinberg S, Snaedal J, Jonsson PV, Bjornsson S, Stefansson H, Sulem P, Gudbjartsson D, Maloney J, Hoyte K, Gustafson A, Liu Y, Lu Y, Bhangale T, Graham RR, Huttenlocher J, Bjornsdottir G, Andreassen OA, Jönsson EG, Palotie A, Behrens TW, Magnusson OT, Kong A, Thorsteinsdottir U, Watts RJ, Stefansson K (2012) A mutation in APP protects against Alzheimer's disease and age-related cognitive decline. Nature 488:96-99

Kandalepas PC, Sadleir KR, Eimer WA, Zhao J, Nicholson DA, Vassar R (2013) The Alzheimer's $\beta$-secretase BACE1 localizes to normal presynaptic terminals and to dystrophic presynaptic terminals surrounding amyloid plaques. Acta Neuropathol 126:329-352

Khoonsari PE, Häggmark A, Lönnberg M, Mikus M, Kilander L, Lannfelt L, Bergquist J, Ingelsson M, Nilsson P, Kultima K, Shevchenko G (2016) Analysis of the cerebrospinal fluid proteome in Alzheimer's disease. PLoS One 11:e0150672

Kim DY, Carey BW, Wang H, Ingano LA, Binshtok AM, Wertz MH, Pettingell WH, He P, Lee VM, Woolf CJ, Kovacs DM (2007) BACE1 regulates voltage-gated sodium channels and neuronal activity. Nat Cell Biol 9:755-764

Kim MH, Gunnersen JM, Tan SS (2002) Localized expression of the seizure-related gene SEZ-6 in developing and adult forebrains. Mech Dev 118:171-174

Kizuka Y, Kitazume S, Fujinawa R, Saito T, Iwata N, Saido TC, Nakano M, Yamaguchi Y, Hashimoto Y, Staufenbiel M, Hatsuta H, Murayama S, Manya H, Endo T, Taniguchi N (2015) An aberrant sugar modification of BACE1 blocks its lysosomal targeting in Alzheimer's disease. EMBO Mol Med 7:175-189
Klevanski M, Herrmann U, Weyer SW, Fol R, Cartier N, Wolfer DP, Caldwell JH, Korte M, Müller UC (2015) The APP intracellular domain is required for normal synaptic morphology, synaptic plasticity, and hippocampus-dependent behavior. J Neurosci 35:16018-16033

Kobayashi D, Zeller M, Cole T, Buttini M, McConlogue L, Sinha S, Freedman S, Morris RG, Chen KS (2008) BACE1 gene deletion: impact on behavioral function in a model of Alzheimer's disease. Neurobiol Aging 29:861-873

Kolata S, Wu J, Light K, Schachner M, Matzel LD (2008) Impaired working memory duration but normal learning abilities found in mice that are conditionally deficient in the close homolog of L1. J Neurosci 28:13505-13510

Konyukh M, Delorme R, Chaste P, Leblond C, Lemière N, Nygren G, Anckarsäter H, Rastam M, Ståhlberg O, Amsellem F, Gillberg IC, Mouren-Simeoni MC, Herbrecht E, Fauchereau F, Toro R, Gillberg C, Leboyer M, Bourgeron T (2011) Variations of the candidate SEZ6L2 gene on chromosome $16 \mathrm{p} 11.2$ in patients with autism spectrum disorders and in human populations. PLoS One 6:e17289

Kuhn PH, Wang H, Dislich B, Colombo A, Zeitschel U, Ellwart JW, Kremmer E, Rossner S, Lichtenthaler SF (2010) ADAM10 is the physiologically relevant, constitutive alpha-secretase of the amyloid precursor protein in primary neurons. EMBO J 29:3020-3032

Kuhn PH, Koroniak K, Hogl S, Colombo A, Zeitschel U, Willem M, Volbracht C, Schepers U, Imhof A, Hoffmeister A, Haass C, Roßner S, Bräse S, Lichtenthaler SF (2012) Secretome protein enrichment identifies physiological BACE1 protease substrates in neurons. EMBO J 31:3157-3168

Kumar RA, Marshall CR, Badner JA, Babatz TD, Mukamel Z, Aldinger KA, Sudi J, Brune CW, Goh G, Karamohamed S, Sutcliffe JS, Cook EH, Geschwind DH, Dobyns WB, Scherer SW, Christian SL (2009) Association and mutation analyses of $16 \mathrm{p} 11.2$ autism candidate genes. PLoS One 4:e4582

Laird FM, Cai H, Savonenko AV, Farah MH, He K, Melnikova T, Wen H, Chiang HC, Xu G, Koliatsos VE, Borchelt DR, Price DL, Lee HK, Wong PC (2005) BACE1, a major determinant of selective vulnerability of the brain to amyloid-beta amyloidogenesis, is essential for cognitive, emotional, and synaptic functions. J Neurosci 25:11693-11709

Lammich S, Kojro E, Postina R, Gilbert S, Pfeiffer R, Jasionowski M, Haass C, Fahrenholz F (1999) Constitutive and regulated alpha-secretase cleavage of Alzheimer's amyloid precursor protein by a disintegrin metalloprotease. Proc Natl Acad Sci U S A 96:3922-3927

Law JW, Lee AY, Sun M, Nikonenko AG, Chung SK, Dityatev A, Schachner M, Morellini F (2003) Decreased anxiety, altered place learning, and increased CA1 basal excitatory synaptic transmission in mice with conditional ablation of the neural cell adhesion molecule L1. J Neurosci 23:10419-10432

Leshchyns'ka I, Sytnyk V, Richter M, Andreyeva A, Puchkov D, Schachner M (2006) The adhesion molecule CHL1 regulates uncoating of clathrin-coated synaptic vesicles. Neuron 52: $1011-1025$

Li B, Woo RS, Mei L, Malinow R (2007) The neuregulin-1 receptor erbB4 controls glutamatergic synapse maturation and plasticity. Neuron 54:583-597

Li Q, Südhof TC (2004) Cleavage of amyloid-beta precursor protein and amyloid-beta precursor-like protein by BACE 1 . J Biol Chem 279:10542-10550

Lichtenthaler SF, Haass C, Steiner H (2011) Regulated intramembrane proteolysis - lessons from amyloid precursor protein processing. $\mathrm{J}$ Neurochem 117:779-796

Lorent K, Overbergh L, Moechars D, De Strooper B, Van Leuven F, Van den Berghe H (1995) Expression in mouse embryos and in adult mouse brain of three members of the amyloid precursor protein family, of the alpha-2-macroglobulin receptor/low density 
lipoprotein receptor-related protein and of its ligands apolipoprotein E, lipoprotein lipase, alpha-2-macroglobulin and the 40,000 molecular weight receptor-associated protein. Neuroscience 65:10091025

Luo X, He W, Hu X, Yan R (2014) Reversible overexpression of BACE1cleaved neuregulin-1 N-terminal fragment induces schizophrenialike phenotypes in mice. Biol Psychiatry 76:120-127

Luo Y, Bolon B, Kahn S, Bennett BD, Babu-Khan S, Denis P, Fan W, Kha H, Zhang J, Gong Y, Martin L, Louis JC, Yan Q, Richards WG, Citron M, Vassar R (2001) Mice deficient in BACE1, the Alzheimer's beta-secretase, have normal phenotype and abolished beta-amyloid generation. Nat Neurosci 4:231-232

Maccarrone G, Ditzen C, Yassouridis A, Rewerts C, Uhr M, Uhlen M, Holsboer F, Turck CW (2013) Psychiatric patient stratification using biosignatures based on cerebrospinal fluid protein expression clusters. J Psychiatr Res 47:1572-1580

Maness PF, Schachner M (2007) Neural recognition molecules of the immunoglobulin superfamily: signaling transducers of axon guidance and neuronal migration. Nat Neurosci 10:19-26

Mariani J, Coppola G, Zhang P, Abyzov A, Provini L, Tomasini L, Amenduni M, Szekely A, Palejev D, Wilson M, Gerstein M, Grigorenko EL, Chawarska K, Pelphrey KA, Howe JR, Vaccarino FM (2015) FOXG1-dependent dysregulation of GABA/glutamate neuron differentiation in autism spectrum disorders. Cell 162:375-390

Meakin PJ, Harper AJ, Hamilton DL, Gallagher J, McNeilly AD, Burgess LA, Vaanholt LM, Bannon KA, Latcham J, Hussain I, Speakman JR, Howlett DR, Ashford ML (2012) Reduction in BACE1 decreases body weight, protects against diet-induced obesity and enhances insulin sensitivity in mice. Biochem J 441:285-296

Mei L, Xiong WC (2008) Neuregulin 1 in neural development, synaptic plasticity and schizophrenia. Nat Rev Neurosci 9:437-452

Mei L, Nave KA (2014) Neuregulin-ERBB signaling in the nervous system and neuropsychiatric diseases. Neuron 83:27-49

Mitsui S, Hidaka C, Furihata M, Osako Y, Yuri K (2013) A mental retardation gene, motopsin/prss12, modulates cell morphology by interaction with seizure-related gene 6 . Biochem Biophys Res Commun 436:638-644

Mitterreiter S, Page RM, Kamp F, Hopson J, Winkler E, Ha HR, Hamid R, Herms J, Mayer TU, Nelson DJ, Steiner H, Stahl T, Zeitschel U, Rossner S, Haass C, Lichtenthaler SF (2010) Bepridil and amiodarone simultaneously target the Alzheimer's disease beta- and gamma-secretase via distinct mechanisms. J Neurosci 30:8974-8983

Miyazaki T, Hashimoto K, Uda A, Sakagami H, Nakamura Y, Saito SY, Nishi M, Kume H, Tohgo A, Kaneko I, Kondo H, Fukunaga K, Kano M, Watanabe M, Takeshima H (2006) Disturbance of cerebellar synaptic maturation in mutant mice lacking BSRPs, a novel brain-specific receptor-like protein family. FEBS Lett 580:4057-4064

Montag-Sallaz M, Schachner M, Montag D (2002) Misguided axonal projections, neural cell adhesion molecule 180 mRNA upregulation, and altered behavior in mice deficient for the close homolog of L1. Mol Cell Biol 22:7967-7981

Mostaid MS, Lloyd D, Liberg B, Sundram S, Pereira A, Pantelis C, Karl T, Weickert CS, Everall IP, Bousman CA (2016) Neuregulin-1 and schizophrenia in the genome-wide association study era. Neurosci Biobehav Rev 68:387-409

Mullan M, Crawford F, Axelman K, Houlden H, Lilius L, Winblad B, Lannfelt L (1992) A pathogenic mutation for probable Alzheimer's disease in the APP gene at the N-terminus of beta-amyloid. Nat Genet 1:345-347

Mullard A (2016) BACE race gains steam. Nat Rev Drug Discov 15:151

Mulley JC, Iona X, Hodgson B, Heron SE, Berkovic SF, Scheffer IE, Dibbens LM (2011) The role of seizure-related SEZ6 as a susceptibility gene in febrile seizures. Neurol Res Int 2011:917565
Müller UC, Zheng H (2012) Physiological functions of APP family proteins. Cold Spring Harb Perspect Med 2:a006288

Nhan HS, Chiang K, Koo EH (2015) The multifaceted nature of amyloid precursor protein and its proteolytic fragments: friends and foes. Acta Neuropathol 129:1-19

O'Tuathaigh CM, Harte M, O'Leary C, O'Sullivan GJ, Blau C, Lai D, Harvey RP, Tighe O, Fagan AJ, Kerskens C, Reynolds GP, Waddington JL (2010) Schizophrenia-related endophenotypes in heterozygous neuregulin-1 'knockout' mice. Eur J Neurosci 31:349-358

Ohno M, Sametsky EA, Younkin LH, Oakley H, Younkin SG, Citron M, Vassar R, Disterhoft JF (2004) BACE1 deficiency rescues memory deficits and cholinergic dysfunction in a mouse model of Alzheimer's disease. Neuron 41:27-33

Ohno M, Chang L, Tseng W, Oakley H, Citron M, Klein WL, Vassar R, Disterhoft JF (2006) Temporal memory deficits in Alzheimer's mouse models: rescue by genetic deletion of BACE1. Eur J Neurosci 23:251-260

Ohno M, Cole SL, Yasvoina M, Zhao J, Citron M, Berry R, Disterhoft JF, Vassar R (2007) BACE1 gene deletion prevents neuron loss and memory deficits in 5XFAD APP/PS1 transgenic mice. Neurobiol Dis 26:134-145

Osaki G, Mitsui S, Yuri K (2011) The distribution of the seizure-related gene 6 (Sez-6) protein during postnatal development of the mouse forebrain suggests multiple functions for this protein: an analysis using a new antibody. Brain Res 1386:58-69

Pitcher GM, Kalia LV, Ng D, Goodfellow NM, Yee KT, Lambe EK, Salter MW (2011) Schizophrenia susceptibility pathway neuregulin 1-ErbB4 suppresses Src upregulation of NMDA receptors. Nat Med $17: 470-478$

Poliak S, Salomon D, Elhanany H, Sabanay H, Kiernan B, Pevny L, Stewart CL, Xu X, Chiu SY, Shrager P, Furley AJ, Peles E (2003) Juxtaparanodal clustering of Shaker-like K+ channels in myelinated axons depends on Caspr2 and TAG-1. J Cell Biol 162:1149-1160

Rajapaksha TW, Eimer WA, Bozza TC, Vassar R (2011) The Alzheimer's $\beta$-secretase enzyme BACE1 is required for accurate axon guidance of olfactory sensory neurons and normal glomerulus formation in the olfactory bulb. Mol Neurodegener 6:88

Sachse CC, Kim YH, Agsten M, Huth T, Alzheimer C, Kovacs DM, Kim DY (2013) BACE1 and presenilin $/ \gamma$-secretase regulate proteolytic processing of KCNE1 and 2, auxiliary subunits of voltage-gated potassium channels. FASEB J 27:2458-2467

Sadleir KR, Kandalepas PC, Buggia-Prévot V, Nicholson DA, Thinakaran G, Vassar R (2016) Presynaptic dystrophic neurites surrounding amyloid plaques are sites of microtubule disruption, BACE1 elevation, and increased A $\beta$ generation in Alzheimer's disease. Acta Neuropathol

Savonenko AV, Melnikova T, Laird FM, Stewart KA, Price DL, Wong PC (2008) Alteration of BACE1-dependent NRG1/ErbB4 signaling and schizophrenia-like phenotypes in BACE1-null mice. Proc Natl Acad Sci U S A 105:5585-5590

Selkoe DJ, Hardy J (2016) The amyloid hypothesis of Alzheimer's disease at 25 years. EMBO Mol Med 8:595-608

Shankar GM, Li S, Mehta TH, Garcia-Munoz A, Shepardson NE, Smith I, Brett FM, Farrell MA, Rowan MJ, Lemere CA, Regan CM, Walsh DM, Sabatini BL, Selkoe DJ (2008) Amyloid-beta protein dimers isolated directly from Alzheimer's brains impair synaptic plasticity and memory. Nat Med 14:837-842

Shimizu-Nishikawa K, Kajiwara K, Sugaya E (1995a) Cloning and characterization of seizure-related gene, SEZ-6. Biochem Biophys Res Commun 216:382-389

Shimizu-Nishikawa K, Kajiwara K, Kimura M, Katsuki M, Sugaya E (1995b) Cloning and expression of SEZ-6, a brain-specific and seizure-related cDNA. Brain Res Mol Brain Res 28:201-210

Stefansson H, Sigurdsson E, Steinthorsdottir V, Bjornsdottir S, Sigmundsson T, Ghosh S, Brynjolfsson J, Gunnarsdottir S, 
Ivarsson $\mathrm{O}$, Chou TT, Hjaltason $\mathrm{O}$, Birgisdottir B, Jonsson $\mathrm{H}$, Gudnadottir VG, Gudmundsdottir E, Bjornsson A, Ingvarsson B, Ingason A, Sigfusson S, Hardardottir H, Harvey RP, Lai D, Zhou M, Brunner D, Mutel V, Gonzalo A, Lemke G, Sainz J, Johannesson G, Andresson T, Gudbjartsson D, Manolescu A, Frigge ML, Gurney ME, Kong A, Gulcher JR, Petursson H, Stefansson K (2002) Neuregulin 1 and susceptibility to schizophrenia. Am J Hum Genet 71:877-892

Stützer I, Selevsek N, Esterházy D, Schmidt A, Aebersold R, Stoffel M (2013) Systematic proteomic analysis identifies $\beta$-site amyloid precursor protein cleaving enzyme 2 and 1 (BACE2 and BACE1) substrates in pancreatic $\beta$-cells. J Biol Chem 288:10536-10547

van Bebber F, Hruscha A, Willem M, Schmid B, Haass C (2013) Loss of BACE2 in zebrafish affects melanocyte migration and is distinct from BACE1 knock out phenotypes. J Neurochem 127:471-481

Vassar R, Kuhn PH, Haass C, Kennedy ME, Rajendran L, Wong PC, Lichtenthaler SF (2014) Function, therapeutic potential and cell biology of BACE proteases: current status and future prospects. J Neurochem 130:4-28

Vassar R, Bennett BD, Babu-Khan S, Kahn S, Mendiaz EA, Denis P, Teplow DB, Ross S, Amarante P, Loeloff R, Luo Y, Fisher S, Fuller J, Edenson S, Lile J, Jarosinski MA, Biere AL, Curran E, Burgess T, Louis JC, Collins F, Treanor J, Rogers G, Citron M (1999) Beta-secretase cleavage of Alzheimer's amyloid precursor protein by the transmembrane aspartic protease BACE. Science 286:735-741

Vnencak M, Paul MH, Hick M, Schwarzacher SW, Del Turco D, Müller UC, Deller T, Jedlicka P (2015) Deletion of the amyloid precursorlike protein 1 (APLP1) enhances excitatory synaptic transmission, reduces network inhibition but does not impair synaptic plasticity in the mouse dentate gyrus. J Comp Neurol 523:1717-1729

Wang H, Song L, Laird F, Wong PC, Lee HK (2008) BACE1 knock-outs display deficits in activity-dependent potentiation of synaptic transmission at mossy fiber to CA3 synapses in the hippocampus. J Neurosci 28:8677-8681

Wang H, Megill A, Wong PC, Kirkwood A, Lee HK (2014) Postsynaptic target specific synaptic dysfunctions in the CA3 area of BACE1 knockout mice. PLoS One 9:e92279
Willem M, Garratt AN, Novak B, Citron M, Kaufmann S, Rittger A, DeStrooper B, Saftig P, Birchmeier C, Haass C (2006) Control of peripheral nerve myelination by the beta-secretase BACE1. Science 314:664-666

Willem M, Tahirovic S, Busche MA, Ovsepian SV, Chafai M, Kootar S, Hornburg D, Evans LD, Moore S, Daria A, Hampel H, Müller V, Giudici C, Nuscher B, Wenninger-Weinzierl A, Kremmer E, Heneka MT, Thal DR, Giedraitis V, Lannfelt L, Müller U, Livesey FJ, Meissner F, Herms J, Konnerth A, Marie H, Haass C (2015) ๆSecretase processing of APP inhibits neuronal activity in the hippocampus. Nature 526:443-447

Wong HK, Sakurai T, Oyama F, Kaneko K, Wada K, Miyazaki H, Kurosawa M, De Strooper B, Saftig P, Nukina N (2005) Beta subunits of voltage-gated sodium channels are novel substrates of betasite amyloid precursor protein-cleaving enzyme (BACE1) and gamma-secretase. J Biol Chem 280:23009-23017

Xu C, Mullersman JE, Wang L, Bin Su B, Mao C, Posada Y, Camarillo C, Mao Y, Escamilla MA, Wang KS (2013) Polymorphisms in seizure 6-like gene are associated with bipolar disorder I: evidence of gene $\times$ gender interaction. J Affect Disord 145:95-99

Yan R, Vassar R (2014) Targeting the $\beta$ secretase BACE1 for Alzheimer's disease therapy. Lancet Neurol 13:319-329

Yu ZL, Jiang JM, Wu DH, Xie HJ, Jiang JJ, Zhou L, Peng L, Bao GS (2007) Febrile seizures are associated with mutation of seizurerelated (SEZ) 6, a brain-specific gene. J Neurosci Res 85:166-172

Zhang Z, Song M, Liu X, Su Kang S, Duong DM, Seyfried NT, Cao X, Cheng L, Sun YE, Ping Yu S, Jia J, Levey AI, Ye K (2015) Deltasecretase cleaves amyloid precursor protein and regulates the pathogenesis in Alzheimer's disease. Nat Commun 6:8762

Zhao J, Fu Y, Yasvoina M, Shao P, Hitt B, O’Connor T, Logan S, Maus E, Citron M, Berry R, Binder L, Vassar R (2007) Beta-site amyloid precursor protein cleaving enzyme 1 levels become elevated in neurons around amyloid plaques: implications for Alzheimer's disease pathogenesis. J Neurosci 27:3639-3649

Zhou L, Barão S, Laga M, Bockstael K, Borgers M, Gijsen H, Annaert W, Moechars D, Mercken M, Gevaert K, Gevaer K, De Strooper B (2012) The neural cell adhesion molecules L1 and CHL1 are cleaved by BACE1 protease in vivo. J Biol Chem 287:25927-25940 